Intecoms: Journal of Information Technology and Computer Science

Volume 2 Nomor 1, Juni 2019

e-ISSN : 2614-1574

p-ISSN : 2621-3249

DOI : https://doi.org/10.31539/intecoms.v2i1.678

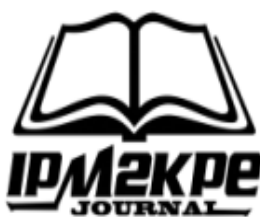

\title{
SISTEM E-INVENTORY MENGGUNAKAN BAHASA PEMOGRAMAN VISUAL BASIC .NET
}

\author{
E-INVENTORY SYSTEM USING \\ THE PROGRAMMING LANGUAGEVISUAL BASIC .NET
}

\author{
Muhardi \\ STMIK Hang Tuah Pekanbaru \\ muhardi.yudie@gmail.com
}

\begin{abstract}
Universal Computer is a business entity in Pekanbaru engaged in the assembly and sale of computers and equipment that do not have a system that integrates well between sales, purchases, and inventory. The recording process is still manual by using the ledger so that the resulting data is less effective and efficient. In addition, the Universal Computer Shop has a weakness in reporting sales, purchases, and inventory that the level of accuracy is still lacking. Entities such as Universal Computer Store will be very good if they have a good information system so that the management of sales, purchases, and inventory in the business will be better. This information system is based on desktop using visual basic programming language. Net and SQL Server 2008 database and information system design that used is Data Flow Diagram (DFD) and ER diagram for business process to be designed. Information systems are provided for Universal Computer Stores to provide convenience to system users, especially employees, suppliers, customers, inventory, goods, and sales, purchasing, sales, inventory, employees, suppliers and customers. It can be concluded that this application is able to assist the Universal Computer Shop in handling the problem of recording purchases, sales, management, inventory, employees, suppliers, customers making reports on purchases, sales, inventory, employees, suppliers, and customers.
\end{abstract}

Keywords: Purchase, Sales, Inventory, Visual Basic. Net, SQL Server 2008

\begin{abstract}
ABSTRAK
Universal Komputer adalah suatu badan usaha di Pekanbaru yang bergerak di bidang usaha perakitan dan penjualan komputer serta perlengkapannya yang belum memiliki sistem yang terintegrasi dengan baik antara penjualan, pembelian, dan persediaan barang. Proses pencatatan masih bersifat manual dengan menggunakan buku besar sehingga data yang dihasilkan kurang efektif dan efesien. Selain itu, Toko Universal Komputer memiliki kelemahan dalam melakukan laporan penjualan, pembelian, dan persediaan yang tingkat ketepatannya masih kurang. Badan uasaha seperti Toko Universal Komputer akan sangat baik sekali jika memiliki sistem informasi yang bagus sehingga manajemen penjualan, pembelian, dan persediaan barang di bidang usaha tersebut akan lebih baik. Sistem informasi ini dibuat berbasis dekstop dengan menggunakan bahasa pemrograman Visual Basic .Net dan database SQL Server 2008 serta perancangan sistem informasi yang digunakan yaitu Data Flow Diagram (DFD) dan ER diagram untuk proses bisnis yang akan dirancang. Sistem informasi disediakan bagi Toko Universal Komputer untuk memberikan kemudahan pada pengguna sistem khususnya bagian pegawai, pemasok, pelanggan, persediaan barang, pembelian barang, dan penjualan barang, pembuatan laporan pembelian, penjualan, persediaan, pegawai, pemasok, dan pelanggan. Dapat disimpulkan bahwa aplikasi ini mampu membantu pihak Toko Universal Komputer dalam menangani masalah pencatatan pembelian, penjualan, pengelolaan, persediaan barang,pegawai, pemasok, pelanggan pembuatan laporan pembelian, penjualan, persediaan, pegawai, pemasok, dan pelanggan
\end{abstract}

Kata Kunci: Pembelian, Penjualan, Persediaan, Visual Basic. Net, SQL Server 2008 


\section{PENDAHULUAN}

Inventory barang merupakan permasalahan operasional yang sering dihadapi oleh toko. Persediaan merupakan sejumlah barang yang disediakan untuk memenuhi permintaan dari pelanggan. Dalam perusahaan perdagangan pada dasarnya hanya ada satu golongan inventori (persediaan), yang mempunyai sifat perputaran yang sama yaitu yang disebut "Merchandise Inventory" (persediaan barang dagangan). Inventori bisa berupa jumlah barang yang diletakkan di etalase toko atau bisa berupa jumlah barang yang disimpan digudang. Perancangan sistem inventori berguna untuk mengontrol persediaan barang pada gudang dan toko buku (Agusvianto, 2017; Fallis, 2013).

Perancangan sistem inventori sudah banyak digunakan dalam suatu organisasi seperti perusahaan, toko, perpustakaan, universitas dan lainnya. Adapun bentuk dari sistem inventori ada yang berupa aplikasi dektop, web maupun mobile phone dalam mempermudah mengawasi alur keluar masuknya barang pada perusahaanya. Hal ini membuat sistem inventori merupakan hal yang sangat penting bagi setiap organisasi(Wisky, 2017; Sari dan Nuari, 2017; Heryanto, dkk., 2014; Indah, 2013).

Universal komputer adalah suatu badan usaha di Pekanbaru yang beralamat di Jalan H. Imam Munandar no 43D, Tangkerang Timur, Tenayan Raya, Kota Pekanbaru, yang bergerak di bidang usaha perakitan dan penjualan komputer serta perlengkapannya. Bisnis utama mereka adalah perakitan komputer dan penjualan laptop, kemudian memasarkan produk jadi ke pasaran Pekanbaru.

Saat ini proses penjualan, pembelian, dan persediaan barang di Universal Komputer masih dilakukan secara manual seperti mengetahui data stok barang serta pembuatan laporannya masih dengan cara penulisan di buku besar adapun alat bantu yang digunakan dalam proses pencatatan yaitu dengan menggunakan Microsoft Excel, sehingga proses pencatatan kurang efektif dan efisien dari segi waktunya. Dengan menggunakan sistem yang berjalan saat ini dibutuhkan banyak waktu untuk proses pencarian barang karena banyaknya jumlah barang, kemudian masalah yang terjadi yaitu adanya redudansi data serta buku catatan persediaan barang rusak atau hilang dan informasi yang dibutuhkan oleh Universal Komputer tidak akurat karena sistem yang berjalan saat ini akan menghambat proses pembuatan laporan.

\section{METODE PENELITAN}

Metode yang d metode waterfall. Secara garis besar metode waterfall mempunyai langkah-langkah sebagai berikut: Analisa, Desain, Penulisan, Pengujian dan Penerapan serta Pemeliharaan (Haryanti \& Irianto, 2011, Sutrabri, 2012).

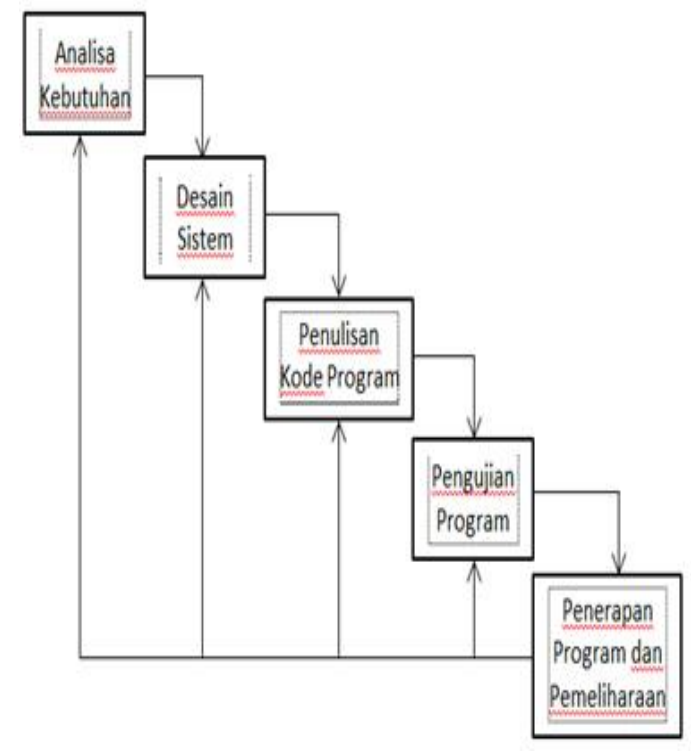

Gambar. 1 Waterfall Model Sumber: (Haryanti \& Irianto, 2011) 
Tahapan Metode Waterfall :

Analisa Kebutuhan. Langkah ini merupakan analisa terhadap kebutuhan sistem di dalam Universal Komputer. Pengumpulan data dalam tahap ini bisa melakukan sebuah penelitian, wawancara atau studi literatur. Sistem analis akan menggali informasi sebanyak-banyaknya sehingga akan tercipta sebuah sistem komputer yang bisa melakukan tugas-tugas yang diinginkan oleh Universal Komputer tersebut. Tahapan ini akan menghasilkan dokumen user requirment di dalam Universal Komputer atau bisa dikatakan sebagai data yang berhubungan dengan keinginan user dalam pembuatan sistem. Dokumen ini lah yang akan menjadi acuan sistem analis untuk menerjemahkan ke dalam bahasa pemograman (Kadir, 2014).

Desain Sistem. Tahapan dimana dilakukan penuangan pikiran dan perancangan sistem terhadap solusi dari permasalahan yang ada di dalam Universal Komputer dengan menggunakan perangkat pemodelan sistem seperti unified modeling language (UML), diagram hubungan entitas (entity relationship diagram) serta struktur dan bahasan data (Rosa dan Salahuddin, 2011)

Penulisan Kode Program Penulisan kode program atau coding merupakan penerjemahan design dalam bahasa yang bisa dikenali oleh komputer. Dilakukan oleh programmer yang akan menterjemahkan kebutuhan yang diminta oleh Universal Komputer. Tahapan ini lah yang merupakan tahapan secara nyata dalam mengerjakan suatu sistem. Setelah pengkodean selesai maka akan dilakukan testing terhadap sistem yang telah dibuat untuk Universal Komputer tadi. Tujuan testing adalah menemukan kesalahan-kesalahan terhadap sistem tersebut dan kemudian bisa diperbaiki (Rosa dan Salahuddin, 2015).

Pengujian Program. Tahapan akhir dimana sistem yang baru diuji kemampuan dan keefektifannya sehingga didapatkan kekurangan dan kelemahan sistem untuk Universal Komputer yang kemudian dilakukan pengkajian ulang dan perbaikan terhadap aplikasi menjadi lebih baik dan sempurna.

Penerapan Program dan Pemeliharaan. Perangkat lunak yang sudah diterapkan pada Universal Komputer pasti akan mengalami perubahan. Review dapat dilaksanakan kira-kira setelah enam bulan berjalan. Tujuannya adalah untuk menyakinkan apakah sistem tersebut berjalan sesuai dengan tujuan semula dan apakah masih ada perbaikan atau penyempurnaan yang harus dilakukan. Perubahan tersebut bisa karena mengalami kesalahan karena perangkat lunak harus menyesuaikan dengan lingkungan (periperal atau sistem operasi baru), atau karena universal komputer membutuhkan perkembangan fungsional.

\section{HASIL DAN PEMBAHASAN Halaman Utama}

Tahap ini merupakan kegiatan pembuatan sistem atau aplikasi dengan menggunakan bantuan perangkat lunak maupun perangkat keras sesuai dengan analisis dan perancangan untukmenghasilkan suatu sistem yang bekerja.

\section{Antarmuka FormLogin}

Untuk mengkakses menu-menu yang ada pada aplikasi ini, Super Admin dan Operator harus melakukan login terlebih dahulu dengan memasukkan username dan password yang telah ditentukan terlebih dahulu. 


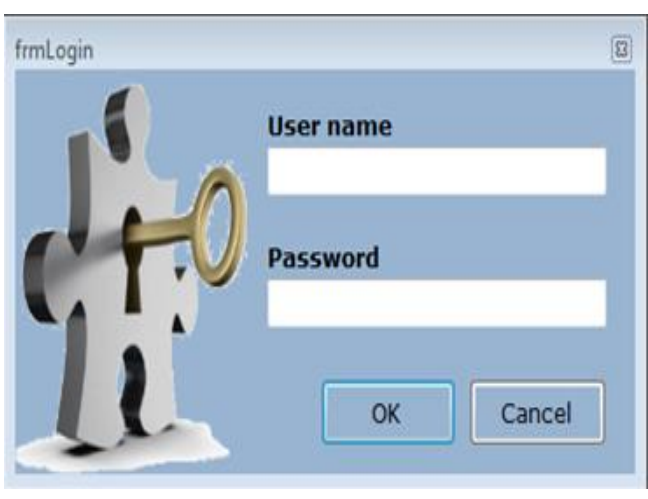

Gambar. 2 Antarmuka frm Login

\section{Antarmuka Form Menu Utama Super Admin}

Setelah login, maka akan diarahkan ke halaman menu utama, dimana jika login sebagai Super Admin, maka tampil halaman home khusus Super Admin, yang terdapat menu File, Master, Transaksi, dan laporan.

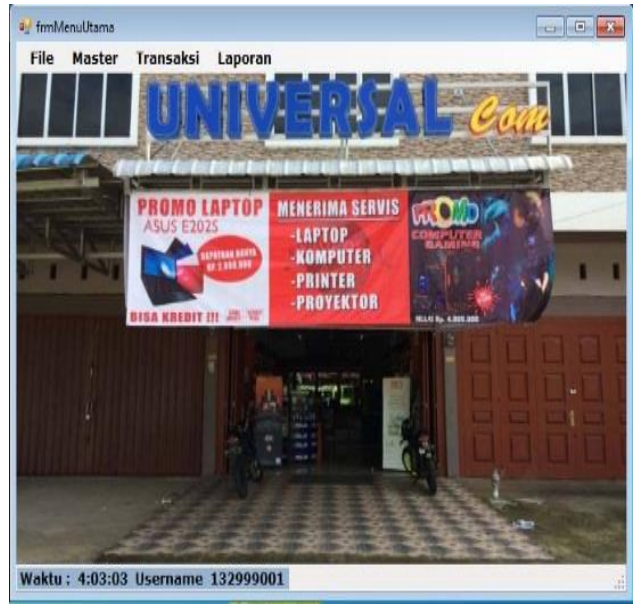

Gambar. 3 Antarmuka frm Menu Utama Super Admin

\section{Antarmuka Form Menu Utama Operator}

Setelah login, maka akan diarahkan ke halaman menu utama, dimana jika login sebagai Operator, maka tampil halaman menu utama khusus operator, yang terdapat menu seperti halam homelogin, perbedaannya hanya tidak ada menu Laporan dan operator juga tidak bisa mengolah admin.

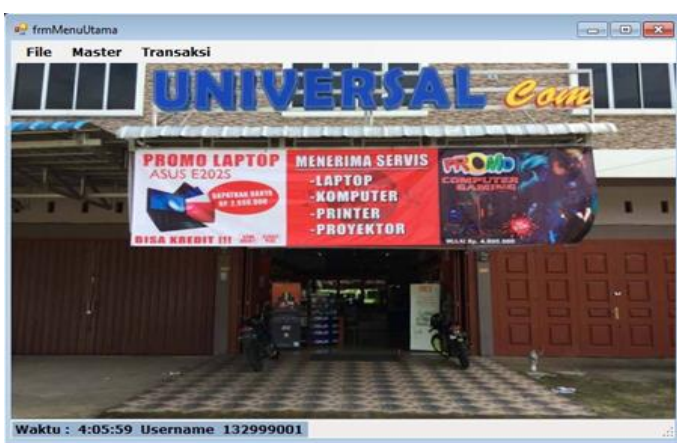

Gambar. 4 Antarmuka form Menu Utama Operator

\section{Antarmuka Form Barang}

Ketika memilih menu Barang, maka akan tampak tabel yang menampilkan isi data dari Tbarang. Pengguna dapat menambah data dengan menekan tombol Tambah Data, atau mengubah dan menghapus data dengan menekan tombol yang terdapat pada frmBarang.

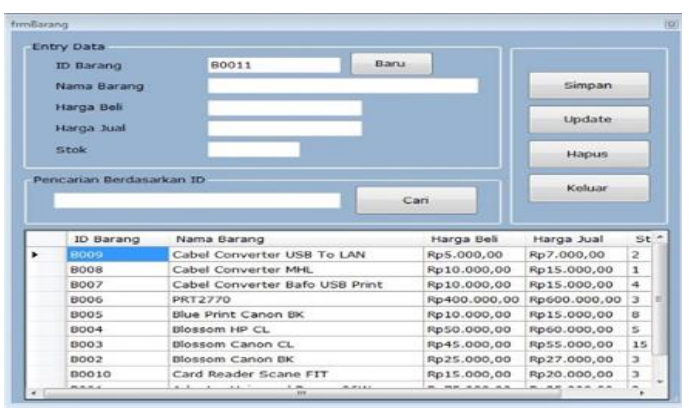

Gambar. 5 Antarmuka frmBarang

\section{Antarmuka Form Pemasok}

Pengguna dapat menambah data dengan menekan tombol Tambah Data, atau mengubah dan menghapus data dengan menekan tombol yang terdapat pada frmPemasok.

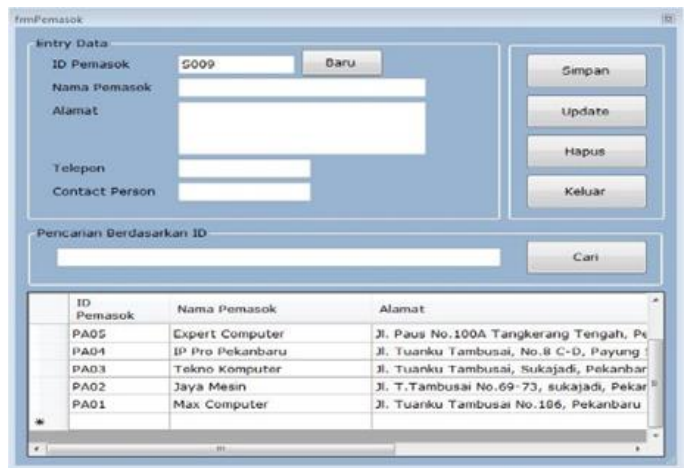

Gambar. 6 Antarmuka Form Pemasok 


\section{Antarmuka Pelanggan}

Ketika memilih menu pelanggan, maka akan tampak tabel yang menampilkan isi data dari Tpelanggan. Pengguna dapat menambah data dengan menekan tombol Tambah Data, atau mengubah dan menghapus data dengan menekan tombol yang terdapat pada frmPelanggan.

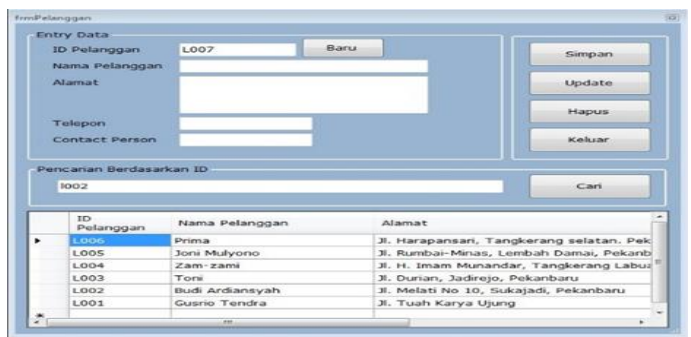

Gambar 7. Antarmuka frmPelanggan

\section{Antarmuka Admin}

Ketika memilih menu Admin, maka akan tampak tabel yang menampilkan isi data dari Tadmin. Pengguna dapat menambah data dengan menekan tombol TambahData, atau mengubah dan menghapus data dengan menekan tombol yang terdapat pada frmAdmin.

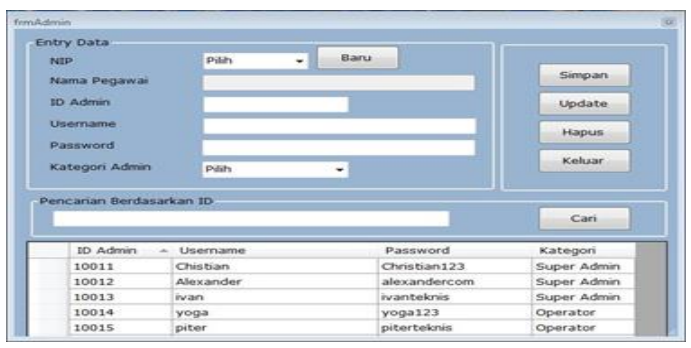

Gambar 8. Antarmuka frmAdmin

\section{Antarmuka Pemesanan}

Ketika memilih menu Pemesanan, maka akan tampak tabel yang menampilkan isi data dari Tpemesanan. Pengguna dapat menambah data dengan menekan tombol Tambah Data, atau membatalkan dan menghapus data dengan menekan tombol yang terdapat pada frmTransPemesanan.

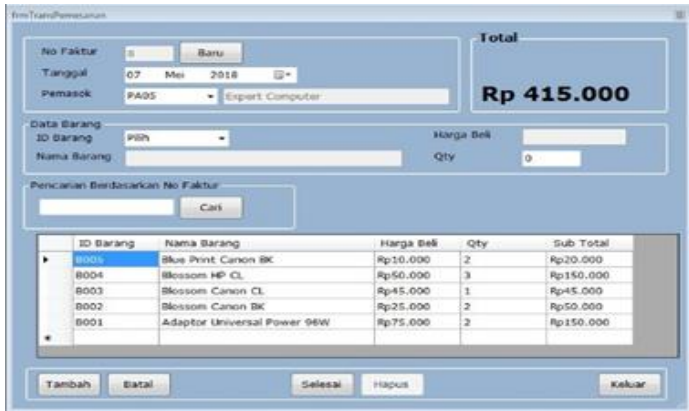

Gambar 9. Antarmuka frmpemesanan

\section{Antarmuka Penjualan}

Ketika memilih menu Penjualan, maka akan tampak tabel yang menampilkan isi data dari Tpenjualan. Pengguna dapat menambah data dengan menekan tombol Tambah Data, atau membatalkan dan menghapus data dengan menekan tombol yang terdapat pada frmTransPenjualan.

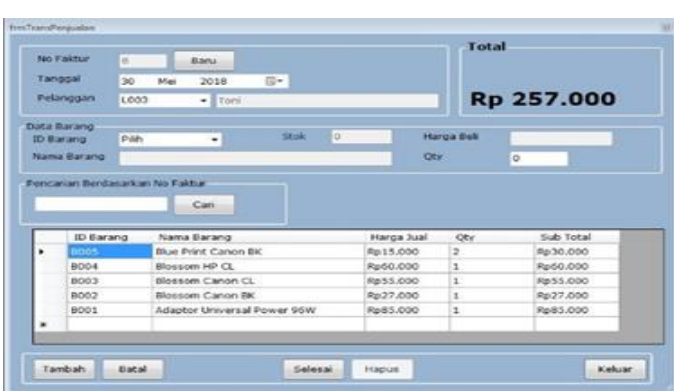

Gambar 10. Antarmuka frmpenjualan

Antarmuka

Laporan

TransaksiPembelian

Setelah menekan tombol Laporan Transaksi Pembelian pada menu Laporan, maka akan diarahkan ke halaman Laporan Pembelian.

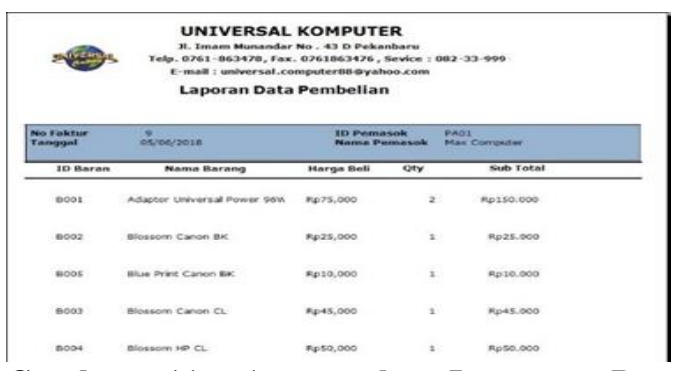

Gambar 11. Antarmuka Laporan Data Pembelian 


\section{Antarmuka Laporan Transaksi Penjualan}

Setelah menekan tombol Laporan Penjualan pada menu Laporan, maka akan diarahkan ke halaman Laporan Penjualan.

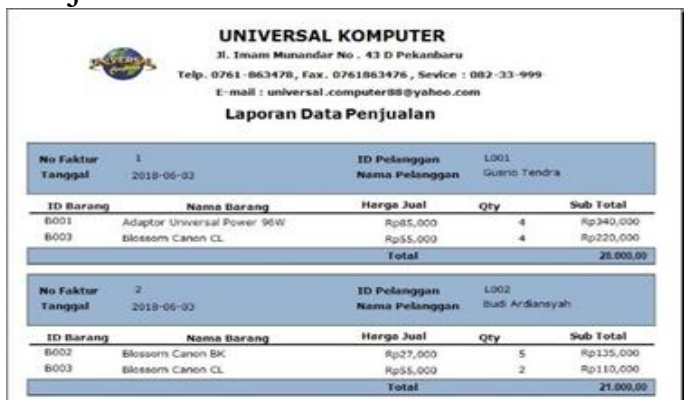

Gambar. 12 Antarmuka Laporan Data Penjualan

\section{Antarmuka Laporan Barang Keluar Masuk}

Setelah menekan tombol Laporan Barang pada menu Laporan, maka akan diarahkan ke halaman Laporan Barang keluar masuk.

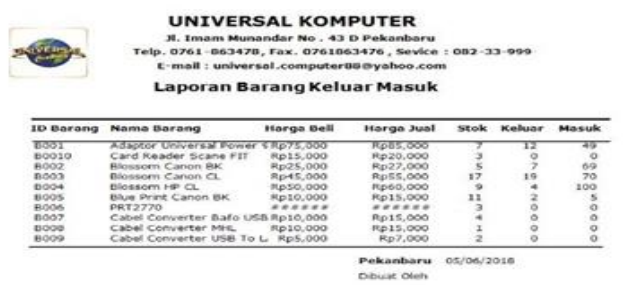

Gambar. 13 Antarmuka Laporan Barang Keluar Masuk

\section{Antarmuka Laporan Pemasok}

Setelah menekan tombol Laporan Pemasok pada menu Laporan, maka akan diarahkan ke halaman Laporan Pemasok.

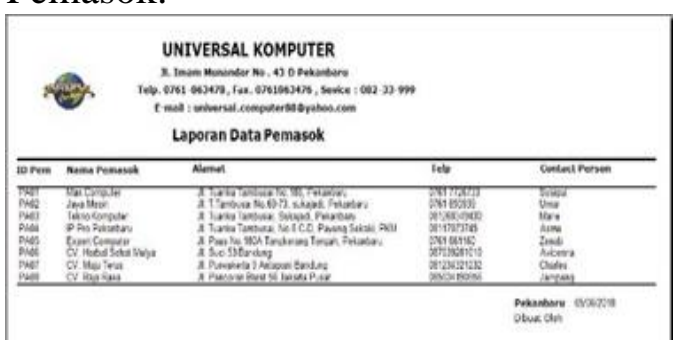

Gambar. 14 Antarmuka Laporan Data Pemasok

\section{Antarmuka Laporan Pelanggan}

Setelah menekan tombol Laporan Pelanggan pada menu Laporan, maka akan diarahkan ke halaman Laporan Pelanggan.

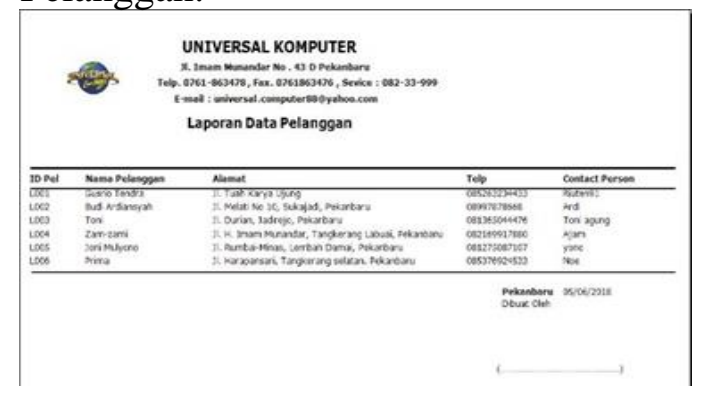

Gambar. 15 Antarmuka Laporan Data Pelanggan.

\section{SIMPULAN}

1. Sistem Informasi Pengolahan Data Persediaan Barang pada Universal Komputer berbasis Visual Basic .Netini tidak menggunakan kertas lagi sebagai bahan penginputan data barang atau faktur transaksi pembelian, faktur transaksi penjualan dan Laporan keluar masuk barang. Sehingga kegiatan memasukkan atau memperbaharui data serta pertukaran informasi menjadi lebih efektif dan efesien.

2. Sistem Informasi Pengolahan Persediaan Data Barang pada Universal Komputer berbasis Visual Basic .Net ini memudahkan user dalam mencari data barang dengan menggunakan fitur pencarian pada aplikasi.

3. Sistem Informasi Pengolahan Persediaan Data Barang pada Universal Komputer berbasis Visual Basic .Net ini memudahkan proses pengolahan data barang, sehingga menghasilkan laporan yang akurat. 
DAFTAR PUSTAKA

Agusvianto, H. (2017). Sistem Informasi Inventori Gudang Untuk Mengontrol Persediaan Barang pada Gudang Studi Kasus : PT. Alaisys Sidoarjo. Journal Information Engineering and Educational Technology, 1(1), 4046

Fallis, A. (2013). Sistem Informasi Pengolahan Data Inventory pada Toko Buku Studi Cv. Aneka Ilmu Semarang. Journal of Chemical Information And Modeling, 53(9), 1689-1699.

Https://Doi.Org/10.1017/Cbo9781 107415324.004

Haryanti, S., \& Irianto, T. (2011). Rancang Bangun Sistem Informasi E-Commerce Untuk Usaha Fashion Studi Kasus Omah Mode Kudus. Journal Speed, 3(1), 8-14.

Https://Doi.Org/10.3112/Speed.V 3i1.889

Sari, O. A., \& Nuari, E. (2017). Rancang Bangun Sistem Informasi Persediaan Barang Berbasis Web Dengan Metode FAST (Framework for the Applications). Jurnal PILAR Nusa Mandiri, 13(2), 261-266

Heryanto, A., Fuad, H., Dananggi, D., Stmik, D., Sarana, B., Stmik, M., \& Sarana, B. (2014). Rancang Bangun Sistem Informasi Inventory Barang Berbasis Web Studi Kasus di PT . Infinetworks Global Jakarta, 4(2), 2-5

Hidayatullah, P. (2014). Visual Basic Net (1st Ed.). Bandung: Informatika Bandung

Indah, I. N. (2013). Pembuatan Sistem Informasi Penjualan pada Toko Sehat Jaya Elektronik Pacitan. Indonesian Jurnal on Computer Science, $\quad 10, \quad 124-128$. Doi.Org/10.3112/Speed.V12i1.11
47

Kadir, A. (2014). Pengenalan Sistem Informasi. (H. Dewi, Ed.). Yokyakarta: Cv Andi Offset

Rosa, R., \& Shalahuddin, S. (2011). Rekayasa Perangkat Lunak. Bandung: Modula

Rosa, R., \& Shalahuddin, S. (2015). Rekayasa Perangkat Lunak. Bandung: Informatika Bandung

Sutabri, T. (2012). Analisis Sistem Informasi. (C. Putri, Ed.). Yokyakarta: $\mathrm{Cv}$ Andi Offset

Wisky, I. A. (2017). Penerapan Aplikasi Sistem Inventory pada Toko Buku Permata dengan Menggunakan Bahasa Pemrograman Visual Basic. Net dan Database Mysql, 7(2), 231-247 